\title{
KEGIATAN PENANAMAN TANAMAN OBAT KELUARGA (TOGA) SEBAGAI SALAH SATU USAHA PEMBERDAYAAN SISWA SDN DERMO GUNA DALAM MENUMBUHKAN KEPEDULIAN KESEHATAN KELUARGA
}

\author{
Sri Rahmawati Fitriatien', Novi Eka Juni Rachmawati², Nazilatur Rahmah ${ }^{3}$, Devi Arisanti Safitri ${ }^{4}$, \\ Muhammad Reza Pahlevi ${ }^{5}$, Nur Miftakh Wakhid Natsir ${ }^{6}$ \\ 1,2,3,4,5,6 Fakultas Keguruan dan Ilmu Pendidikan , Universitas PGRI Adi Buana Surabaya \\ email : rahmawatien.srf@unipasby.ac.id ${ }^{1}$, novieka191@ gmail.com², nazilaturrahmah16@gmail.com ${ }^{3}$, \\ sarieshanty@yahoo.com ${ }^{4}$, muhammadrezaapahl@gmail.com ${ }^{5}$, nurmiftakh@yahoo.com $^{6}$
}

\begin{abstract}
Abstrak
Tanaman obat keluarga (TOGA) merupakan tanaman yang memiliki banyak khasiat terutama dalam bidang kesehatan. Karena banyaknya khasiat dari tanaman TOGA maka dalam Kegiatan Pengabdian pada masyarakat (PPM) yang berbentuk pelatihan ini dilakukan pelatihan penanaman TOGA dengan menanam tanaman obat keluarga ini. Pelatihan ini diperuntukan bagi siswa SDN Dermo Kecamatan Benjeng Kabupaten Gresik. Tujuan PPM ini yaitu dengan memanfaatkan tanaman TOGA dapat meningkatkan derajat kesehatan secara mandiri dengan memanfaatkan Tanaman yang bersifat obat, serta memberi pengetahuan kepada seluruh siswa akan pentingnya Toga bagi kesehatan dan memberi pemahaman tentang cara penanaman dan perawatan TOGA yang baik serta membiasakan para siswa dan juga guru untuk menanam tumbuhan terutama TOGA di lingkungan sekolah. Metode yang digunakan yaitu active learning dan parcipatory learning, yang meliputi ceramah, demontrasi, pratek penanaman TOGA dan dilanjutkan dengan diskusi hasil pelatihan ini. Hasil pelatihan ini menunjukkan pengetahuan siswa SDN Dermo meningkat tentang pentingnya dan manfaat Tanaman TOGA bagi kesehatan dan lingkungan.
\end{abstract}

Kata Kunci:Pemberdayaan, Penanaman, Tanaman Obat Keluarga (TOGA)

\section{PENDAHULUAN}

\section{A. Latar Belakang}

Kegiatan KKN (Kuliah Kerja Nyata) merupakan wujud nyata pelaksanaan tentang pengabdian kepada masyarakat yang merupakan suatu kebijakan pemerintah. Hal ini dapat diperlihatkan dari beberapa faktor yang digunakan sebagai landasan-landasan yang telah ditetapkan pemerintah sebagai program nasional.

Dewasa ini obat-obatan modern sudah menjadi bagian dari kehidupan kita seharihari. Obat-obatan itu dalam berbagai bentuk sudah dijual bebas dan mudah sekali didapatkan dengan harga yang relatif terjangkau seluruh lapisan masyarakat. Akhir-akhir ini trend pengobatan modern cenderung kembali ke tanaman obat yang digunakan secara tradisional. Ada beberapa alasan yang mendasari kecederungan ini diantaranya tanaman obat keluarga ini aman dikonsumsi dan bisa menyembuhkan penyakit tanpa menimbulkan efek samping dibandingkan dengan obat-obatan modern terutama yang dibuat dari bahan sintesis.
Alasan lain, obat-obatan tradisional juga lebih tepat untuk digunakan sebagai penyakit atau untuk menjaga kesehatan. Bahkan sekarang Pemkot Gresik secara rutin melombakan penghijauan dari tanaman obat. Karena lomba seperti ini dianggap mempunyai banyak manfaat.

Yang dimaksud dengan TOGA adalah Tanaman Obat Keluarga. Taman obat keluarga pada hakekatnya sebidang tanah baik di halaman rumah, kebun ataupun ladang yang digunakan untuk membudidayakan tanaman yang berkhasiat sebagai obat dalam rangka memenuhi keperluan keluarga akan obat-obatan. Bagian tanaman yang dapat dimanfaatkan sebagai obat yaitu bagian daun, kulit batang, buah, biji, bahkan bagian akarnya.jenis tanaman yang dibudidayakan sebagai TOGA adalah tanaman yang tidak meerlukan perawatan khusus, tidak mudah diserang hama penyakit, bibitnya mudah didapat, mudah tumbuh dan tidak termasuk jenis tanaman terlarang dan berbahaya atau beracun. Pemanfaatan tanaman TOGA tersebut dapat 
mengatasi masalah-masalah kesehatan. Hal ini menunjukkan bahwa obat yang berhasil dari sumber bahan alam khususnya tanaman telah memperlihatkan perannya dalam penyelenggaraan upaya-upaya kesehatan.

Dalam pelaksanaan praktek lapangan ini, memberikan kesempatan bagi mahasiswa untuk melakukan latihan, penerapan dan pengalaman ilmu pengetahuan yang telah diperoleh dari bangku perkuliahan dan dilakukan di lingkungan masyarakat, sekolah dan sebagainya sehingga kehadiran mahasiswa dalam praktek lapangan ini dapat memberikan suatu ilmu, bantuan pemikiran, tenaga dan teknologi juga seni dalam merencanakan dan melaksanakan kegiatan dalam segala bidang khususnya bidang kesehatan.

Pelatihan yang akan dilakukan yaitu tentang penanaman TOGA yaitu kegiatan meletakkan bibit tanaman TOGA di pekarangan dengan memanfaatkan lahan yang ada, yang kemudian dari hasil tanaman tersebut dapat dimanfaatkan dalam kehidupan sehari-hari. Tanaman obat yang akan ditanam di pekarangan sekolah diantaranya jahe, kunyit, kunyit putih, lengkuas dan lidah buaya. Karena tanaman obat tersebut memiliki banyak manfaat dan dapat digunakan untuk mengatasi berbagai penyakit ringan seperti batuk, masuk angin maupun penyakit berat seperti kanker dan lain-lain. Tanaman obat juga dapat dijadikan alternatif berobat yang lebih aman dan alami. Selain itu, tanaman obat juga baik untuk menjaga kecantikan dan kesehatan kulit dan tubuh. Tanaman obat dapat dikonsumsi dengan cara diolah terlebih dahulu. Beberapa tanaman obat dapat digunakan sehari-hari dan diolah dengan cara sederhana seperti direbus dan dicampur dengan air atau bahanbahan lainnya.

Pada kesempatan ini kami selaku mahasiswa Universitas PGRI Adi Buana Surabaya yang sedang melakukan kegiatan KKN PPM memfokuskan pada kegiatan penanaman dan pemanfaatan Tanaman Obat Keluarga (TOGA). Pemanfaatan penanaman TOGA harus sedini mungkin dijelaskan manfaatnya kepada anak-anak supaya mereka tahu bagaimana khasiat dan pentingnya tanaman obat itu. Dari pada obatobatan yang dikemasan modern biasanya mengandung efek atau alergi kepada pengonsumsi itu sendiri. Di SDN Dermo, mahasiswa KKN-PPM melaksanakan penyuluhan yang berbentuk pelatihan dan penanaman TOGA di lingkungan sekolah. Dari kegiatan penanaman TOGA para siswa jadi tahu pentingnya tumbuh-tumbuhan ternyata memiliki khasiat untuk mengobati penyakit tanpa membeli obat-obatan modern.

\section{B. Landasan Teori}

\section{1) Pengertian TOGA}

Tanaman Obat Keluarga (disingkat TOGA) adalah tanaman hasil budidaya rumahan yang berkhasiat sebagai obat. Taman obat keluarga pada hakekatnya adalah sebidang tanah, baik di halaman rumah, kebun ataupun ladang yang digunakan untuk membudidayakan tanaman yang berkhasiat sebagai obat dalam rangka memenuhi keperluan keluarga kan obat-obatan. Kebun tanaman obat atau bahan obat dan selanjutnya dapat disalurkan kepada masyarakat, khususnya obat yang berasal dari tumbuh-tumbuhan.

\section{2) Fungsi TOGA}

Salah satu fungsi TOGA adalah sebagai sarana untuk mendekatkan tanaman obat kepada upaya-upaya kesehatan masyarakat yang antara lain meliputi:

a. Upaya preventif (pencegahan)

b. Upaya promotif (meningkatkan derajat kesehatan)

c. Upaya kuratif (penyembuhan penyakit)

Selain fungsi di atas ada juga fungsi lainnya yaitu:

a. Sarana untuk memperbaiki satus gizi masyarakat, sebab banyak tanaman obat yang dikenal sebagai tanaman penghasil buah-buahan atau sayursayuran misalnya lobak, saledri, papaya dan lain-lain.

b. Sarana untuk pelestarian alam

Apabila pembuatan tanaman obat alam tidak diikuti dengan upayaupaya pembudidayaannya kembali, maka sumber bahan obat alam itu terutama tumbuh-tumbuhan akan mengalami kepunahan.

c. Sarana penyebaran gerakan penghijauan 
Untuk menghijaukan bukit-bukit yang saat ini mengalami pengundulan, dapat dianjurkan penyebarluasan penanaman tanaman obat yang berbentuk pohon misalnya pohon asam, pohon kedaung, pohon trengguli dan lain-lain.

d. Sarana untuk pemertaan pendapatan

TOGA disamping berfungsi sebagai sarana untuk menyediakan bahan obat bagi keluarga dapat pula berfungsi untuk sebagai sumber penghasilan bagi keluarga tersebut.

e. Sarana keindahan

Dengan adanya TOGA dan bila ditata dengan baik maka hal ini akan menghasilkan keindahan bagi orang atau masyarakat yang ada disekitarnya. Untuk menghasilkan keindahan diperlukan perawata terhadap tanaman yang ditanam terutama yang ditamam di pekarangan (lahan) sekolah.Pemeliharaan terdiri atas pemupukan, pemangkasan (tanaman tertentu), penyesuaian waktu tanam, penyiangan untuk populasi gulma, penimbunan dan penggemburan tanah temapat tubuh, dan pengairan.

\section{3) Pemanfaatan Tanaman TOGA}

Penanaman tanaman obat di pekarangan, selain dimanfaatkan untuk obat, juga dapat ditata dengan baik sebagai penghias pekarangan. Pekarangan rumah akan menjadi tampak asri dan penghuninya juga dapat memperoleh obat-obatan yang diperlukan untuk menjaga kesehatan. Tanaman obat yang dipilih untuk di tanam di pekarangan biasanya adalah tanaman obat yang dapat dimanfaatkan untuk pertolongan pertama atau obat-obat ringan seperti demam dan batuk. Tanaman obat yang sering di pekarangan, antara lain sirih, kunyit, jahe, jeruk nipis, temulawak dan sebagainya.

Pemanfaatan TOGA umumnya untuk pengobatan gangguan kesehatan keluarga menurut gejala- gejala umum seperti demam panas, batuk, sakit perut, gatal-gatal dan sebagainya. Pada saat anggota keluarga ada yang sakit, TOGA dapat dijadikan sebagai alternative obat tradisional yang paling mudah dicari, tidak menghabiskan uang untuk membeli, dan memiliki efek samping yang jauh lebih rendah tingkat bahayanya dari pada obat-obatan kimia.

Berikut ini aneka jenis tanaman TOGA yang memiliki khasiat dan manfaat meliputi:

\section{a. JAHE (Zingiber officinale)}

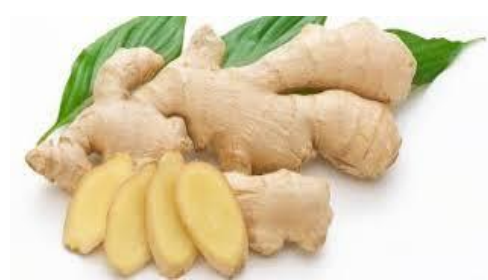

Gambar 1. Jahe sebagai Tanaman TOGA

Umbi jahe mengandung senyawa oleoresin yang lebih dikenal sebagai gingerol yang bersifat sebagai antioksidan. Sifat inilah yang membuat jahe disebut-sebut berguna sebagai komponen bioaktif antipenuan. Manfaat jahe diantaranya membantu pencernaan, mengatasi masuk angin, demam dan batuk, menyembuhkan sakit perut, membantu dalam mengobati batu empedu, mencegah beberapa jenis penyakit kanker, mengurangi rasa sakit dan pembengkakan, meredakan migrain dan kram sakit menstruasi, mengurangi sakit gigi, dan menurunkan kadar kolestrol.

b. KUNYIT (Curcuma longa Linn)

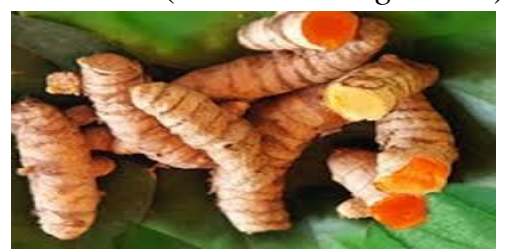

Gambar 2. Kunyit sebagai Tanaman TOGA 
Kunyit merupakan tanaman obat berupa semak dan bersifat tahunan yang tersebar di seluruh daerah tropis. Manfaat kunyit diantaranya mengatasi diabetes mellitus, tifus, usus buntu, disentri, sakit keputihan, haid tidak lancer, perut mulas sakit haid, memperlancar ASI, mengatasi cangkrang, amandel dan berak lendir.

\section{c. LIDAH BUAYA (Aloe vera)}

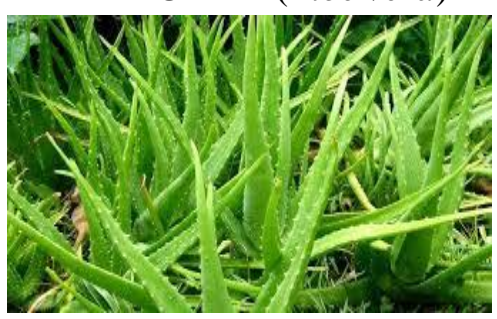

Gambar 3. Lidah Buaya sebagai Tanaman TOGA

Lidah buaya adalah sejenis tumbuhan yang sudah dikenal sejak ribuan tahun silam dan digunakan sebagai penyubur rambut, penyembuh luka dan untuk perawatan kulit. Tanaman iini kaya akan kandungan zat-zat seperti enzim, asam amino, mineral, vitamin, polisakarida, dan komponen lain yang sangat bermanfaat bagi kesehatan. Manfaat lidah buaya diantaranya menyuburkan rambut, menyembuhkan luka, dijadikan untuk perawatan kulit, meningkatkan sistem ketebalan tubuh, melakukan detoksifikasi (pengeluaran racun dalam tubuh), diet/mengurangi berat badan, membantu sistem pencernaan, mencegah peradangan, dan mengobati wasir.

\section{METODE}

\section{A. Sasaran Kegiatan}

Sasaran dalam kegiatan penanaman TOGA yaitu siswa SDN Dermo, Kecamatan Benjeng, Kabupaten Gresik. Kegiatan ini tepatnya dikuti oleh siswa kelas $\mathrm{V}$ yang berjumlah 18 siswa dan siswa kelas VI yang berjumlah 12 siswa.

\section{B. Metode Kegiatan}

Metode yang digunakan dalam kegiatan ini yaitu
1. Active and participatory learning. Metode ini meliputi kegiatan ceramah mengenai alat dan bahan untuk penanaman TOGA, cara penanaman TOGA, dan manfaat dari penanaman TOGA, serta praktek penanaman TOGA yang dilakukan oleh siswa SDN Dermo. Penggunaan metode ini dapat memberikan materi relatif banyak secara padat, cepat, dan mudah.

2. Demontrasi

Metode demontrasi digunakan untuk menunjukkan suatu proses kerja sehingga memberikan kemudahan bagi peserta pelatihan.

Demontrasi dilakukan oleh mahasiswa KKN-PPM sebagai narasumber untuk menyampaikan atau mempratekkan penanaman TOGA.

\section{Bahan dan Alat}

Alat yang digunakan dalam penanaman TOGA yaitu:

1) Polibag

2) Pot

3) Ember

4) Gayung

5) Sekrup

Bahan yang digunakan dalam proses penanaman TOGA yaitu:
1) Tanah
2) Pupuk (kompos)
3) Bibit atau tanaman obat
4) Air

\section{Langkah-langkah kegiatan}

Siswa SDN Dermo diinfokan untuk berkumpul di lapangan sekolah untuk diberi penyuluhan dan pelatihan. Sebelum demonstrasi dan praktek para peserta pelatihan diberi ceramah tentang cara penanaman dan perawatan TOGA yang benar serta khasiat TOGA untuk kesehatan. Adapun langkah-langkah kegiatan KKN-PPM ini melalui tahapan sebagai berikut:

1) Persiapan merupakan perencanaan program pengabdian yang meliputi: (a) koordinasi dengan pihak sekolah 
lokasi pengabdian, (b) penetapan waktu pelatihan, (c) penentuan sarana dan target peserta pelatihan, dan (d) perencanaan materi pelatihan.

2) Pelaksanaan, untuk meningkatkan pengetahuan siswa SDN Dermo tentang khasiat TOGA secara ilmiah dan tata cara menanam TOGA. Pelatihan dilakukan oleh mahasiswa KKN-PPM untuk penyamaan persepsi dengan peserta. Pelatihan dilakukan dengan penyediaan sarana dan prasarana kegiatan pengabdian dalam upaya peningkatan pengetahuan dan keterampilan siswa SDN Dermo, diantarannya kegiatan yang dilakukan yaitu penyuluhan tentang pentingnya tanaman obat, pengadaan bibit-bibit tanaman obat, pelatihan teknik penanaman tanaman obat, pelatihan pengklasifikasi jenis tanaman obat, dan pemanfaatan hasil tanaman obat.

Secara umum cara penanaman TOGA sebagai berikut:

1) Menyiapkan alat dan bahan yang digunakan untuk penanaman Toga terlebih dahulu.

2) Campurkan tanah dan kompos (pupuk) sebagai media tanam toga dengan perbandingan 2:1

3) Siapkan polybag atau pot yang digunakan sebagai wadah penanaman toga

4) Masukan sebagian campuran tanah dan kompos ke poyibag atau pot

5) Setelah itu, taruh tanaman atau bibit obat pada media polybag atau pot

6) Kemudian masukan campuran tanah dan kompos ke polybag atau pot lagi

7) Letakkan polybag di tempat yang teduh/tidak terkena cahaya matahari langsung

8) Lakukan perawatan dan penyiraman tanaman obat secara rutin
Adapun cara menanam tanaman obat keluarga adalah sebagai berikut:

1) Jahe

Cara menanamnya sebagai berikut:

a. Pertama, campurkan bahan seperti tanah berhumus, sekam, dan juga pupuk kandang. Perbandingannya 3 banding 1 , artinya jika anda mengunakan tanah 3 ember tanah, maka campurkanlah dengan 1 ember pupuk kandang dan 1 ember sekam.

b. Siapkan bibit jahe yang hendak anda gunakan. Ambil bibit jahe dari indukan dan simpan di tempat yang lembab dan tertutup. Setelah tumbuh tunas, ambil indukan tadi dan mulailah memotongnya menjadi bibit kecil. Per bibit usahakan ada 2 tunas. Setelah itu, rendah itu, rendam bibit di dalam laritan agrimicin $0,1 \%$ selama kurang lebih 8 jam. Setelah itu, angkat dan keringkan

c. Selanjutnya, mulailah memasukan tanah yang telah dicampur pupuk kandang dan sekam ke dalam plastik polybag. Isi hingga memenuhi $3 / 4$ katong. Kemudian sisipkan di dalamnya bibit jahe yang telah disediakan pada langkah yang kedua.

d. Umumnya jahe akan tumbuh setelah 3 bulan. Nah di minggu awal penanaman bibit, jangan lupa untuk terus menyiram polybag dengan air agar medium tanah dan bibit menyatu dengan baik.

e. Setelah jahe tumbuh, lakukan proses pemeliharaan standar seperti pemupukan. Gunakan campuran urea dan $\mathrm{KCl}$ saat 
jahe berusia satu bulan. Perbandinganya 3 : 4 . Per polybag mendapat 1 sendok teh saat jahe memasuki umur 3 bulan, kurangi takaran menjadi 1 sendok teh per polybag.

f. Langkah pemeliharaan selanjutnya, tindangkan prevensif dan reprensif pada hama dan penyakit. Gunakan pestisida dan perhatikan sistem drainase. Jangan sampai air mengenang dan menjadikan rimpan jahe busuk.

g. Terakhir adalah proses memanenan. Umumnya di usia 8 bulan, jahe sudah bisa ditanam.

2) Kunyit

Cara menanamnya sebagai berikut :

a. Siapkan beberapa rimpang kunyit yang berkualitas bagus. Potonglah rimpang tersebut menjadi beberapa bagian yang $\begin{array}{lll}\text { berukuran } & 3-7 & \mathrm{~cm}\end{array}$ menggunakan culter. Usahakan setiap potongan rimpang ini mempunyai 3 mata tunas.

b. Potongan-potangan rimpang kunyit lantas dihamparkan diatas rampah. Proses penyamaian dilakukan dengan menaruh tampah tersebut di ruangan yang kondisinya lembab untuk memicu pertumbuhan tunas. Kerjakan proses ini selama beberapa hari sampai panjang tunas kunyitmencapai $2-3 \mathrm{~cm}$.

c. Siapkan media tanam untuk penanaman bibit kunyit. Campurkan tanah dan pupuk kandang dengan perbandingan $2: 1$. Aduk kedua bahan ini sampai benar-benar rata. Lalu masukkan kedalam polybag yang sudah dibuat lubang sebanyak 3-5 buah.

d. Bibit kunyit yang telah siap kemudian ditanamkan di polybag pada kedalaman 3-5 $\mathrm{cm}$ tergantung bentuk bibit tersebut. Bibit cukup ditanamkan hingga seluruh bagian rimpangnya tertutupi oleh tanah dan tunasnya tetap berada diatas permukaan tanah.

e. Setelah itu, polybag bisa anda pindahkan di tempat yang terbuka agar mendapatkan sinar matahari secara langsung. Disarankan letakkan semua polybag di rak sehingga kapasitas lahan dalam menampung polybag akan semakin besar.

f. Pemeliharaan tanaman kunyit dilakukan dengan menyiramnya secara rutin sehari sekali. Berikan tambahan pupuk kandang secukupnya di media tanam untuk menjaga tingkat kesuburannya. Bersihkan pula media tanam tersebut dari rumput-rumput liar yang tumbuh di atasnya.

3) Lidah Buaya

Cara menanamnya sebagai berikut :

Cara penanaman lidah buaya tidaklah sulit, hampir sama dengan tanaman yang lainnya. Caranya yaitu, ambillah lidah buaya anakan ( masih kecil ) dan tanam seperti menanam tanaman lain. Namun, menanam lidah buaya jangan terlalu dalam dan dangkal karena dapat mengakibatkan bibit busuk dan roboh.

E. Faktor Pendukung dan Penghambat

1) Faktor pendukung 
a. Antusisme peserta untuk mendapatkan pengetahuan tentang tanaman obat keluarga yang bermanfaat.

b. Melimpahnya sumberdaya hayati yang menjadi bahan baku yang dijadikan untuk penanaman TOGA.

2) Faktor penghambat

a. Kurangnya lahan yang digunakan untuk penanaman TOGA.

b. Kondisi lingkungan yang memiliki curah hujan yang rendah yang mengakibatkan tanah menjadi kering. Diperlukan perawatan rutin untuk tumbuhan itu hidup, maka dari itu diperlukan kerjasama yang baik anatara guru dan siswa untuk menjaga TOGA agar tumbuh dengan baik.

\section{HASIL DAN PEMBAHASAN}

Berdasarkan kegiatan penanaman dan pemanfaatan TOGA yang telah mahasiswa KKN-PPM lakukan di lingkungan SDN Dermo hasil yang diperoleh dalam program kegiatan ini berjalan dengan baik. pihak sekolah sangat antusias dalam melaksanakan kegiatan penanaman dan pemanfaatan TOGA bagi kesehatan dan lingkungan sekolah. Walaupun selama kegiatan terjadi sedikit kendala pada saat siswa menanam TOGA dikarenakan lahan yang kurang. Walaupun demikian para siswa mash sangat semangat melakukan penanaman tumbuhan obat ini dengan saling bekerjasama dengan mahasiswa dan siswa-siswi sekolah dan hasil dari proses kegiatan ini berjalan dengan baik. identifikasi masalah didapatkan dan dirumuskan berdasarkan hasil observasi dimana lingkungan di daerah ini memiliki curah hujan yang rendah yang menyebabkan tanah menjadi kering. Sehingga menjadikan tumbuhan di daerah ini susah untuk hidup, diperlukan perawatan yang sangat baik untuk menjaga tumbuhan supaya tumbuh dengan baik.
Adapun hasil dari pelaksanaan kegiatan ini antara lain:

a. Meningkatnya kesehatan siswa SDN Dermo yaitu dengan adanya sosialisasi penyuluhan pentingnya TOGA yang dapat menambah ilmu pengetahuan dan siswa dapat memanfaatkan secara optimal TOGA disekitar lingkungan sekolah.

b. Pelestarian lingkungan hidup yaitu dengan bukti adanya sebuah pusat TOGA di sekolah SDN Dermo yang dimana dalam pengembangannya untuk sarana belajar dan bermain anak usia dini. Selain itu juga adanya tanaman obat keluarga di lingkungan sekolah yang dapat dimanfaatkan secara optimal untuk pengobatan maupun untuk pelestarian lingkungan hidup.

Berikut ini dokumentasi siswa SDN Dermo dalam kegiatan penanaman TOGA yaitu:

1. Proses pencampuran media tanam (pupuk dan tanah liat)

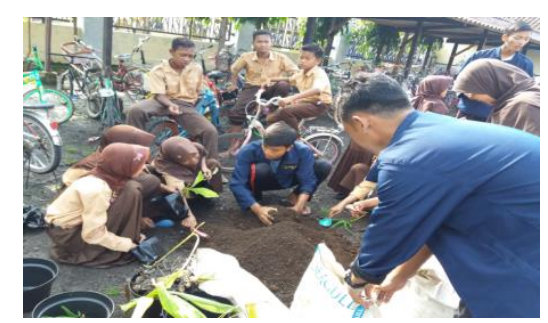

Gambar 4. Penyuluhan Awal Bahan-bahan Proses Tanam TOGA

\section{Proses penanaman Toga}

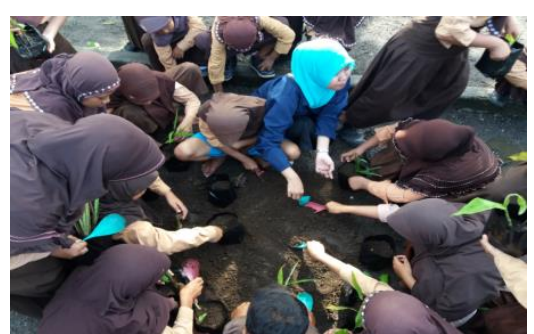

Gambar 5. Penyuluhan Proses Tanam TOGA 


\section{Hasil kegiatan penanaman TOGA}

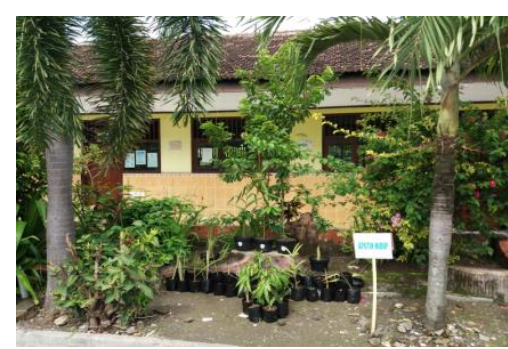

Gambar 6. Hasil Tanam TOGA di Halaman Sekolah

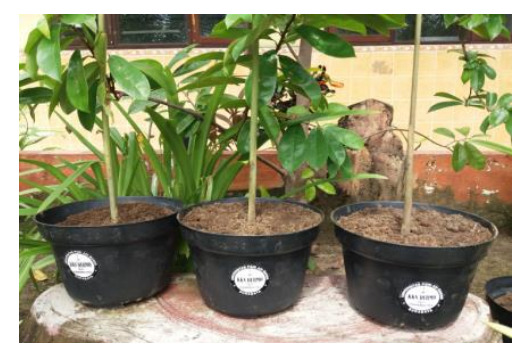

Gambar 7. Hasil Tanam TOGA dalam Pot Tanaman

\section{KESIMPULAN}

Berdasarkan hasil kegiatan yang telah dilaksanakan pada tanggal 18 Februari 2017 dapat disimpulkan bahwa:

a. Dalam pelaksanaan kegiatan penanaman dan pemanfaatan TOGA yang telah mahasiswa KKN-PPM lakukan di SDN Dermo mendapatkan hasil yang baik dan cukup memuaskan. Para siswa jadi lebih mengenal apa itu tumbuhan TOGA dan bagaimana cara pemanfaatnya untuk kesehatan.

b. Dari pelaksanaan kegiatan ini siswa menjadi aktif dan tertarik dalam mengembangkan pemanfaatan tanaman obat

c. Dengan adanya pusat TOGA dapat memanfaatkan tanaman tersebut untuk meningkatkan kesehatan.

d. Penanaman tanaman obat akan dapat mengurangi pencemaran udara dan pemamasan global yang akhir-akhir ini baru digalakan.

e. Dengan adanya pusat tanaman obat dapat melestarikan lingkungan hidup yang ada disekitarnya.

\section{REFERENSI}

https://Alwiyansyah.blogspot.co.id/2013/11

/pengembangan-tanaman-obat-keluarga

https://e-journal.uajy.ac.id

https://reposity.usu.ac.id

https://blogku8994.blogspot.com

https://fentykurniasari.wordpress.com/2015 /02/25makalah-tanaman-toga/

www.yudhe.com/tanaman-dan manfaatnya/ https://id.m.wikipedia.org/wiki/tanaman_o bat_keluarga

http://dokumen.tips/documents/artikeltoga.html

Sarwono, B dan Setiadi, R. 2007. Tanaman Obat Keluarga: 200 Resep Herbal untuk 100 Penyakit. Jakarta: PT. Gramedia.

Redaksi Agromedia. 2007. Memanfaatkan Pekarangan untuk Taman Obat Keluarga. Jakarta: PT. Agromedia Pustaka.

Rukmana, R., dkk., 1996. Kunyit Budidaya dan Pasca Panen. Yogjakarta: Kanisius. http://library.usu.ac.id/downlo

Tukiman. 2004. Pemanfaatan Tanaman Obat Keluarga(TOGA) untuk Kesehatan Keluarga. By USU digital library. http://library.usu.ac.id/download/fkmtukiman.pdf, diakses tanggal 28 februari 2008.

Rukmana, R. H. 2004. Temu-temuan: Apotik Hidup di Pekarangan. Yogjakarta: Kanisius (Anggota IKAPI)

Suriawiria, H.U. 2000. Obat Mujarab dari Pekarangan Rumah. Jakarta: Papas Sinar Sinanti. 